

\section{Making sustainable land management work for women smallholders}

Recommendations for policy makers, and programme implementers, based on evidence from case studies in Benin and Burkina Faso

May 2019

Written by

Larissa Stiem-Bhatia

TMG Research gGmbH

Bruno St-Jacques

TMG Research gGmbH

Saydou Koudougou

Groupe de Recherche et d'Action sur le Foncier (GRAF)

Yvette Onibon Doubogan

Initiative Yara Obirin Dide (YOD)

Acknowledgements

We would like to express our gratitude to all individuals and organisations who generously shared their time and experiences during this collaborative research process. We would also like to thank our partner, the Deutsche Gesellschaft für Internationale Zusammenarbeit (GIZ) GmbH, for their support throughout the accompanyingresearch project. We thank the reviewers for their valuable comments.

Contact

larissa.stiem-bhatia@tmg-thinktank.com

\section{Key messages}

1 Land tenure insecurity is a major obstacle for smallholder farmers wishing to invest in soil protection and rehabilitation. Securing access to land for those most affected by it - especially women, youth and migrants - is crucial.

2 Sustainable Land Management is very labour-intensive.

2 A lack of labour limits women in experimenting and applying a range of SLM technologies. Therefore, supporting farmer groups that pool labour is essential.

3 Soil protection starts with knowledge. Gender-discriminatory norms, attitudes and behaviours that limit women's access to information need to be challenged.

4 Women face more limitations than men in accessing agricultural equipment, credit and inputs, leading to lower adoption rates of SLM technologies. Intra-household dynamics need to be understood in order to alleviate gender imbalances.

5 Research is key for the design of gender-sensitive approaches, and comprehensive data collection is indispensable to track progress on gender indicators. But monitoring activities need to go beyond female participation ratios and other numeric measures to track progress towards gender equality.

6 The persistent gender gap in agriculture can only be tackled through structural change by 2030 . Giving women smallholder farmers equal opportunities is fundamental to reaching gender equality in agriculture and requires everyone's involvement and commitment. 


\section{Why does gender matter in Sustainable Land Management?}

Soil degradation is a root cause of decelerated growth in agricultural productivity and continuous food insecurity in sub-Saharan Africa (FAO \& ITPS, 2015). Driven by inadequate farming prac tices, deforestation and climate change, land degradation costs the economy of sub-Saharan Africa approximately US\$68bn per year and reduces its annual agricultural GDP by 3\% (Nkonya et al.

Decision-makers have recognised the urgency of halting land degradation and have subscribed to numerous large-scale landscape restoration initiatives, including AFR100, the Bonn Challenge and the Regreening Africa initiative. Ensuring that all land users benefit from these programmes is key to keeping the promise of Leaving no one behind in Agenda 2030.

Our analysis of 20 programmes and projects promoting sustainable land management (SLM) in Benin and Burkina Faso of the past 20 to 30 years showed that female farmers do not participate in and benefit from these programmes as much as male farmers do (Assogba et al., 2017; Koudougou \& Stiem, 2017)
Considering gender in the policy design and implementation of SLM is important because:

Women play an important role in Sub-Saharan African agriculture. They are responsible for the large brunt of household food production. In sub-Saharan Africa, women make up 49 percent of

Achieving gender equality in smallholder farming is not only a human rights issue but also a necessity to alleviate rural poverty and food insecurity.

Raising participation along with agricultural productivity of female farmers has been an important vehicle to increase the continent's food supply (Palacios-Lopez, Christiaensen \& Kilic, 2015). It is estiChristions $5 \%$ Kilic, 2015). It is estimated that $55 \%$ of the gains in the fight against hunger between 1970 and 1995 in 63 developing countries were due to the improvement of women's position in society (Smith \& Haddad, 2000).

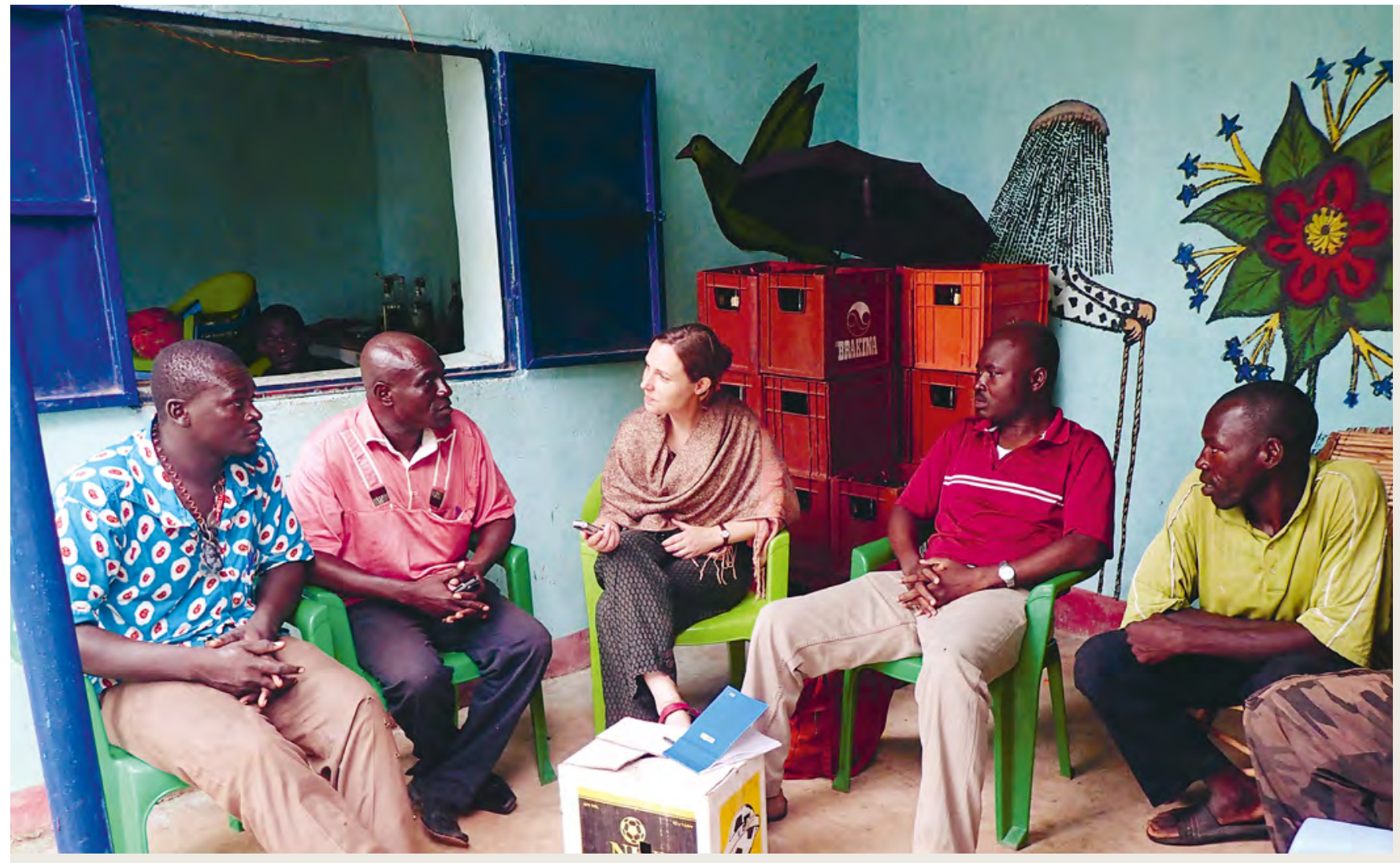

Photo 1: Focus group disc ( $)$ B. Baziemo/GRAF

Analysing gender-specific barriers to soil management in local contexts

The division of labour in farming, crop-choice, and land allocation differs according to gender, and so does soil management. Therefore, the longterm success of initiatives for SLM resides in our understanding of the factors determining farmers' adoption of soil improving practices in their specific context.

The initiative One World, No Hunger is financed by the German Federal Ministry for Economic Cooperation and Development (BMZ). TMG Research, a sustainability think tank based in Berlin, has led the accompanying research component of the global programme on Soil Protection and Rehabilitation for Food Security. In the research project in Benin and Burkina Faso, the authors of this policy brief analysed the enabling factors and constraints authors of this policy brief analysed the enabling factors and constrants ( We conducted 33 focus groups and 116 individual interviews with farmers (men and women), resource people (such as extension agents), and representatives of village authorities. 


\section{Key Message \#1}

Land tenure insecurity is a major obstacle for smallholder farmers wishing to invest in soil protection and rehabilitation. Securing access to land for those most affected by it especially women, youth and migrants is crucial

Our gender studies revealed tenure insecurity and negligence of women's fields as the most important obstacle for women's abilities to invest in SLM in central and northern Benin and southwestern Burkina Faso (Koudougou \& Stiem, 2017; Stiem-Bhatia et al., 2017). Under customary land governance systems in most regions of West Africa, women access land through male family members and only have use rights to land.

Perceived land tenure insecurity limits investments in SLM

Our case studies in Benin and Burkina Faso found that land allocated to women is usually less fertile (Koudougou \& Stiem, 2017; Stiem-Bhatia et al., 2017). Women run a higher risk of losing this land by improving its soil productivity (for example, by planting legumes such as the pigeon pea). The land right holder - their husband in most cases - often seizes the more productive land to grow cash crops. In discussions with farmers, we found that men consider this rotation system, also referred to as forced rotation (see Figure 1), as an efficient resource management, whereas women are discouraged from sustainably investing in soil productivity. In this regard, perceived tenure insecurity restricts the plantation of (semi-)perennial crops, trees, and other soil improving technologies whose effects, such as the enhancement of soil's organic matter and the formation of micro-terraces through sediment tion of micro-terraces through sediment accumulation, are only visible after severalyears. For example, women in Benin reported refraining from planting soi enriching pigeon peas due to their threeyear cycles, as men can withdraw their land use rights at any time (Stiem-Bhatia et al., 2017).

Land tenure insecurity also affects youth and migrants

Youth who access land through the household head may also be affected by forced rotation of fields. Migrants see their SLM investment options restricted by insecure tenure arrangements. They are not allowed to plant trees or build permanent constructions, as these would result in claiming ownership of the leased plot. In addition to those restrictions, migrants have generally less incentives to invest in SLM due to insecure land tives to invest se rights.

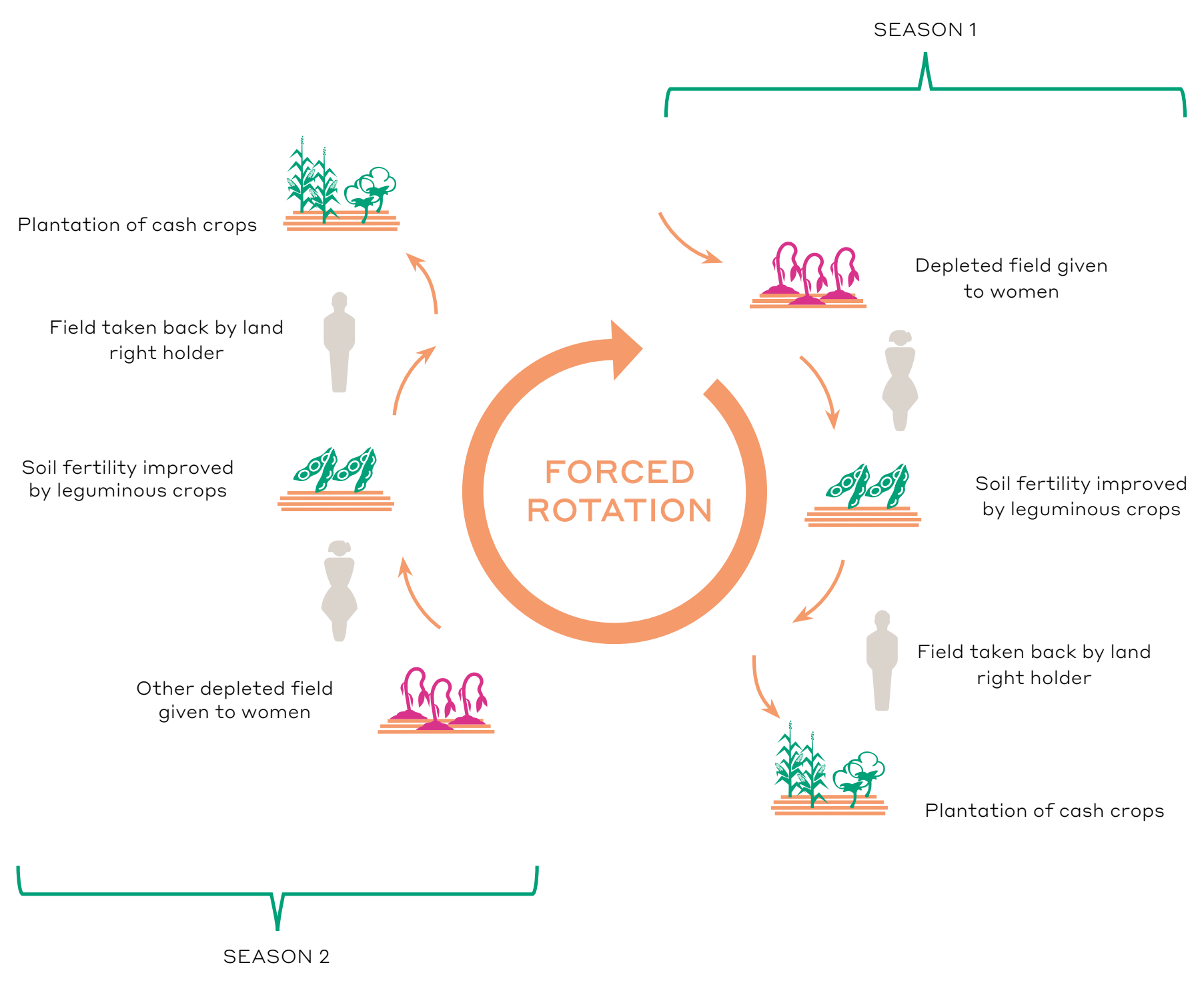




\section{Lack of linking SLM and land tenure in project design and implementation}

Despite strong links between (perceived) tenure insecurity and investments in SLM, few projects tackle tenure insecurity. Our review of SLM projects in southwestern Burkina Faso over the past 20 years found that only three out past 20 years found that only three out
of ten SLM projects dedicate project of ten SLM projects dedicate project activities to land access (Koudougou and
Stiem, 2017). Land security processes are usually part of long and often politically sensitive processes that don't always fit within the timeframe of SLM projects. As a consequence, a gen sal excuse for neglecting tenure issues is that human resources and other capacities were not allocated to these structural hindrances in project design.

\section{Recommendations}

Tenure insecurity is a main hurdle to halting land degradation and increasing agricultural production. Therefore, policies for land degradation neutrality (LDN) must integrate or link to policies on securing access to land. Policies promoting secure and equitable access to land for women promise to enhance the efficiency of land use.

Addressing tenure insecurity as an integral activity of SLM interventions can enable everyone to engage in rehabilitating and protecting their soils. Linking concrete objectives and associated budgets to activities that clarify and budgets to activities that clarify and secureaccess to landwithin sLM-related programmes and tant step.

Policies and programmes seeking to secure land access for women and disadsecure land access for women and disadvantaged/marginalised groups must be further tailored to local realities. While land-lease agreements may be suitable for landless farmers, intra-household tenure agreements could provide more equitable land allocation within land-owning families.

\section{Social innovations for increasing access to land for women}

Intra-household tenure arrangements

(developed in Burkina Faso)

Between 2017 and 2018, TMG Research and GRAF - a Burkinabé network of experts specialized in land governance - worked with the community and other local actors to come up with an innovative instrument to secure land use rights for women in the village of Tiarako in the Satiri district of southwestern Burkina Faso. Intra-household arrangements on land tenure were negotiated between the head of the household and his spouse or other female relatives. These negotiations aimed to change existing tenure arrangements towards enhanced equality and security for women. Today, land use rights for 228 women in the pilot village of Tiarako have been clarified and stabilised for 189 plots ( 2.2 ha on average) covering a total area of 400 ha.

Community-led land lease guidelines (developed in Western Kenya)

TMG Research and Shibuye Community Health Workers (SCHW) - a grassroots community-based organization - developed an innovative way to increase access to farming land, particularly for women. In collaboration with a local community in Western Kenya, TMG Research and SCHW developed land lease guidelines aimed at improving leasing relations and reducing conflicts related to land leasing. The novelty of these land lease guidelines is that they were produced with the community in a process based on inclusion (disadvantaged groups, such as women and youth, contributed actively) and consensus (agreements on the terms and conditions of the guidelines). 


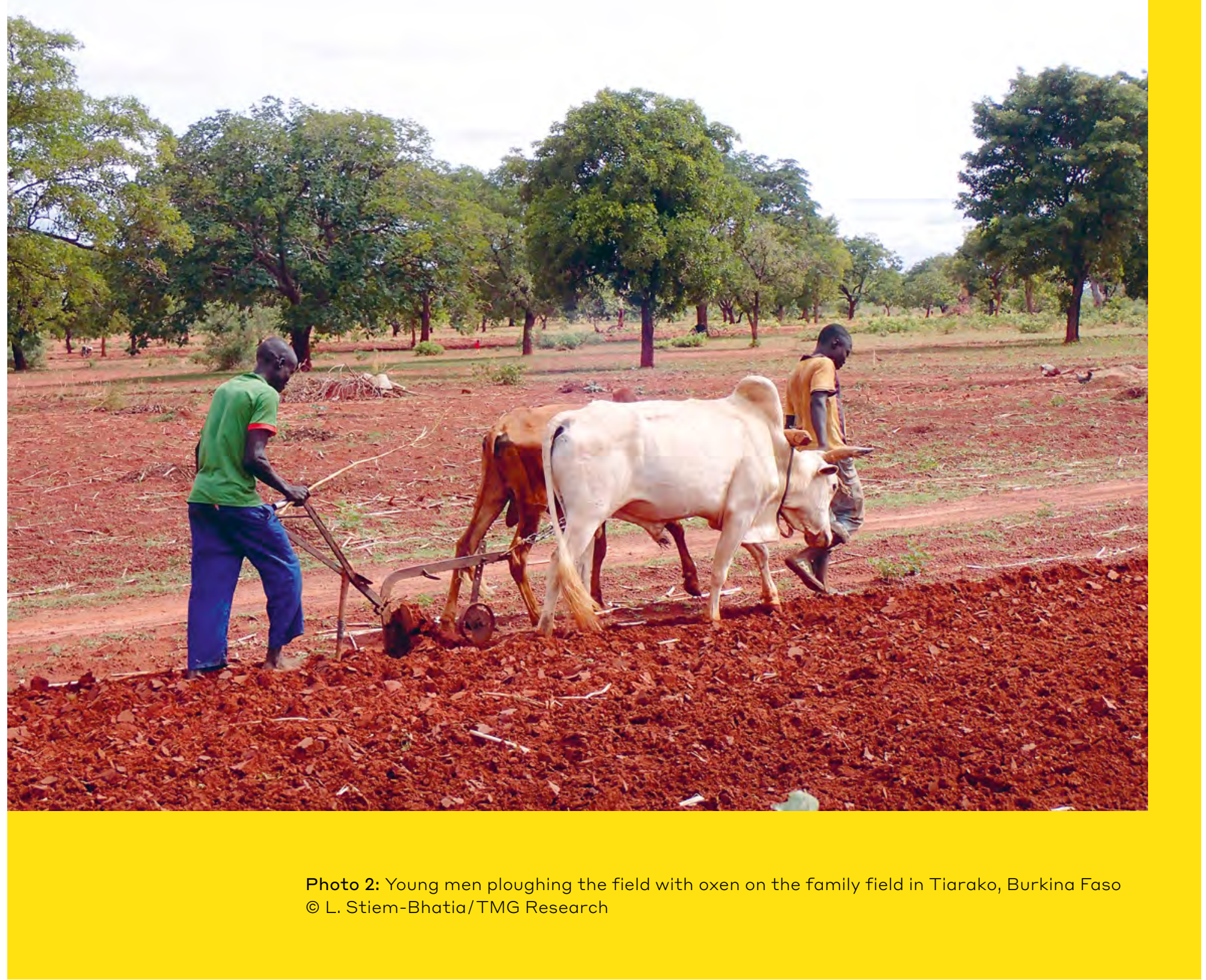

Key Message \#2

Sustainable Land Management is very labour-intensive. A lack of labour limits women in experimenting and applying a range of SLM technologies. Therefore, supporting farmer groups that pool labour is essential.

Labour shortage hits

women harder

Women's access to additional labourers plays a crucial role in their adoption of SLM technologies. Studies show that a lack of labour availability constrains women more than men, for example in decisions about adopting soil improving methods (Quisumbing \& Pandolfelli, 2010). Additionally, men can more easily adopt labour-intensive strategies since they have greater decision-making power over their wives' labour allocation than married women have over the labour of their husbands or sons (Theriault, Smale \& Haider, 2017).

The vastness of land and low levels of mechanisation increase the time constraints of farmers in northern Benin. The few labour resources available are pooled and prioritised to work on fields managed by men (Stiem-Bhatia et al., 2017). Most women struggle to farm 'their fields' after work has been completed on the family fields (held by men). As less importance is attributed to these fields, women also receive delayed support by other family members in tasks such as ploughing their land.
"We get ox to plough our fields very late. Men first take care of their own field before they would come and help us with ours. Therefore we are often late for the rains in our activities. But the rains do not wait for Us.)

(Individual interview with female farmer, Sinawongourou, northern Benin) 


\section{Limited financial resources mean} limited access to labour

Due to limited access to financial resources, women have a harder time than men accessing paid labour. Based on data that we collected from 200 households in two study sites in Benin, only 14 percent of women were able to recruit their own labour, as opposed to 51 percent of men (see Figure 2).

With scarce time resources due to difficulties in recruiting additional farm labour, women often refrain from investing in labour-intensive and time-consuming practices that improve soil (Stiem-Bhatia et al., 2017). Not surprisingly, women reportedly pay less attention to experimenting with new SLM technologies.

\section{Recommendations}

Support women, youth, and gender-mixed farmer groups that effectively pool labour resources for farming. Project implementers should prioritise existing structures, such as informal self-help groups, whose members have already built a certain degree of ownership instead of creating new institutions.

In many contexts, farmer groups and co-operatives can benefit from extension services and other support services provided by the state or NGOs only when they are formalised. Formalising women, youth, and gender-mixed farmer groups can help them gain access to thes

Increase women's access to financia resources through improved agriculto enable them to recruit additional to enable them to recruit add farm labourers. This effort would additionally create work for youth, who are often hired as labourers for agriculture in rural areas.
Recruitment of labour by sex

Survey of 200 households in Kabanou and Sinawongourou, northern Benin. $n=169$

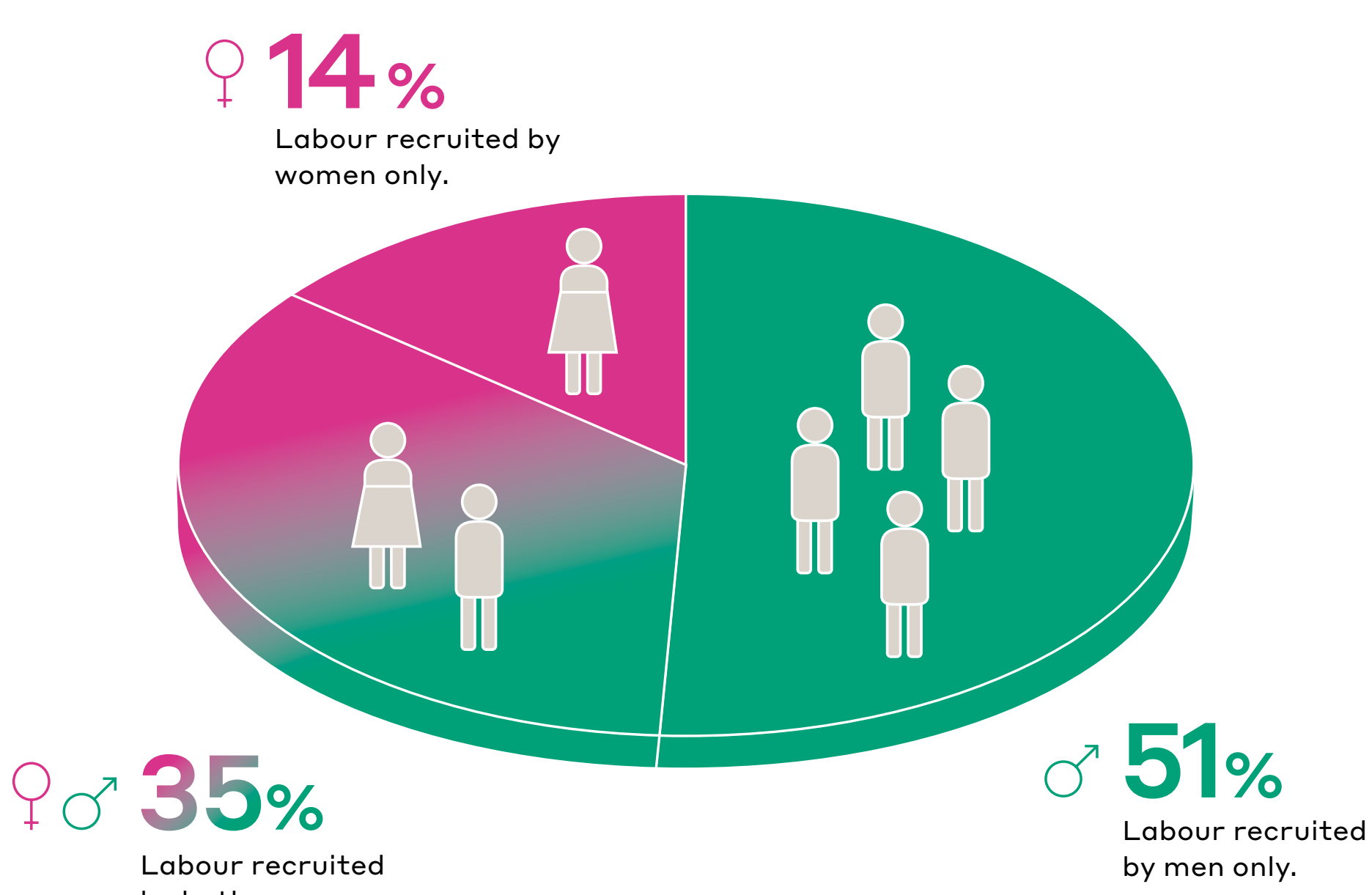




\section{Alits}

Key Message \#3

Soil protection starts with knowledge.

Gender-discriminatory norms, attitudes and

behaviours that limit women's access to

information need to be challenged.

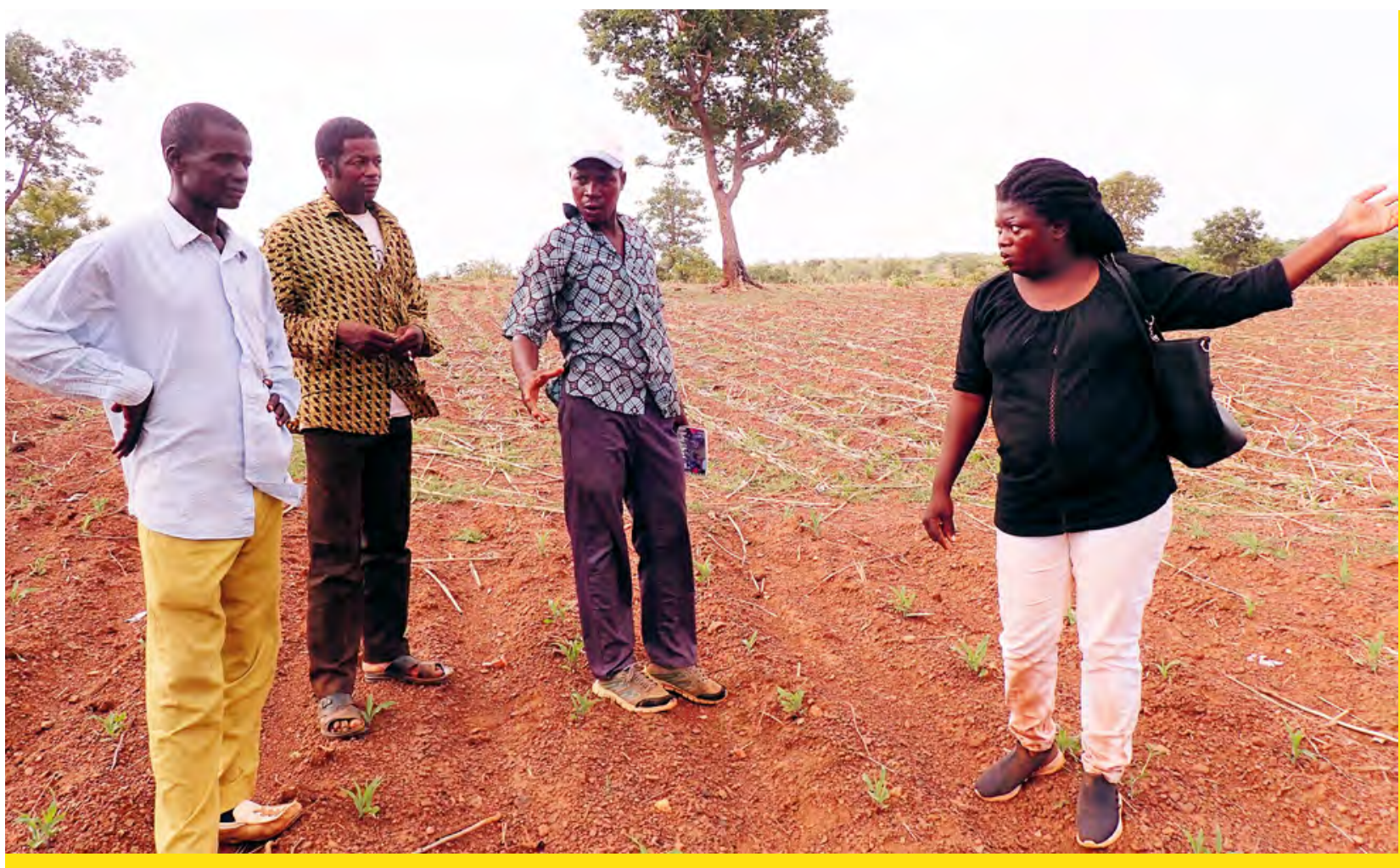

Photo 3: Female extension agent with male farmers

in Bouere, Hounde district, Burkina Faso - a rare picture

๑) L. Stiem-Bhatia/TMG Research
Awareness and knowledge of soil protection and rehabilitation measures is very important for SLM. Our research in West Africa shows that agricultural extension agents interact less with female than male farmers. One reason is gendered norms that constrain women's interaction with male extension workers; another is the focus of extension agents on cotton producers, who are more likely to be men than women in the studied areas (Koudougou et al. 2017; Stiem-Bhatia et al., 2017). Likewise, female farmers may simply feel more comfortable interacting with female extension agents. Since female agents are reportedly less numerous than male agents, women's access to extension services is effectively constrained.

Gendered norms limit opportunities to participate in trainings

Women participate less in trainings on soil management due to gendered norms and perceptions. Field research in western Burkina Faso revealed that men categorically excluded women from trainings about compost production due to prejudices about women's capabilities (Koudougou et al., 2017). Men justified exclusion of women from these trainings due to their traditionally perceived ings due to their traditionaly perceived limited physical capacities and learning capabilities to manage compost production. In other instances, women are traditionally not allowed to manage compost pits because the pits resemble graves (Koudougou et al., 2017).

Knowledge transfer of SLM

technologies and practices is often very technica

Training modules often include instructions for the timing of sowing, the spacing of rows, angles of contour ploughing, etc. While these specificities are important for the adequate application of the technologies and the enhancement of yields, socio-cultural factors that constrain SLM technology adoption, like those outlined above, are seldomly part of SLM trainings (Stiem-Bhatia et al. 2017).

\section{Recommendations}

In the context of male-dominated extension service delivery, gendered norms that impinge on female-male interaction must be challenged along with prejudice against women and their physical and learning capacities so that women can acquire and implement knowledge about new SLM technologies.

To increase the reach of women farmers, extension officers can be incentivised to advise women and other marginalised groups. At the same time, accountability mechanisms need to be put in place to allow women farmers to provide feedback about the actual extension service delivery.

- Awareness raising and integration of social issues in SLM training sessions can reduce socio-cultural hindrances to women's adoption of SLM technology. Project implementers can steer joint Project implementers can steer joint reflections with farmers to dissolve these gender-specific barriers.

Governments and donors should invest in public extension services that not only focus on profits and cash crops but also cater to the needs of women, such as subsistence farming. 


\section{Key Message \#4}

Women face more limitations than men in accessing agricultural equipment, credit and inputs, leading to lower adoption rates of SLM technologies. Intra-household dynamics need to be understood in order to alleviate gender imbalances.

A vast body of research shows that women in smallholder farming are more limited than men in accessing agricultural equipment and other inputs, leading to lower adoption rates of SLM technologies in the long run (Omonona et al., 2006; Mignouna et al., 2011: Lavison, 2013; Obisesan, 2014; Mishra et al., 2015; Muriithi, 2018).

Inequal access to

equipment and inputs

Decision-making and the distribution of rights within the household have implications on tenure, use of labour, and access to agricultural equipment - factors that impact women's ability to apply and develop SLM technologies (Theis et al., 2018). Our findings from Benin clearly show that men are the decision-makers in households. Women need to ask their husbands for permission to plant trees and, in some cases, even consult them on the choice of crops (such as legumes).
As a result, women's low decision-making authority impacts their choices of SLM technologies (Stiem-Bhatia et al., 2017).

Limited access to equipment constrains use of organic fertilizers

Women's limited access to agricultura equipment causes constraints to the application of soil fertility enhancing technologies. In the studied areas of Benin and Burkina Faso, women struggle to spread large quantities of manure and compost on their fields in most cases due to limited access to transport equipment (Koudougov et al., 2017; Stiem-Bhatia et al., 2017). Despite the challenges associated with the application of these soil fertility management measures, manure and compost present an important alternative to mineral fertilisers for women. Extension agents often privilege men - as heads of the family farm and cotton producers in accessing mineral fertilisers as weers in accessing mineral fertilisers as well as credit (Stiem-Bhatia et al., 2017).
SLM projects often neglect these intra-household genderimbalances

Most projects focus on technology application rates; few consider women's abilities and motivations to continue the application of a technology (Theis et al., 2018). Similarly, we observed that restricted access to inputs and agricultural equipment are dealt with peripherally in SLM technology trainings (Assogba et al., 2017; Koudougou \& Stiem, 2017). Negligence of these intra-household factors may also explain the low adoption rates after project withdrawal (Assogba et al., 2017; Koudougou \& Stiem, 2017).

Stark differences between women within female-headed and male-headed households

The disadvantaged position of women farmers as compared to men and the special difficulties of widowed women is crucial to consider in gender-sensitive approaches to SLM. The observed differences between widowed and married women are significant in Burkina Faso. In the studied areas, widows usually experienced less tenure insecurity than single or married women (Koudougou et al., 2017) but are comparatively more affected by limited access to seeds, labour, and agricultural equipment in managing their land sustainably.

\section{Recommendations}

Intra-household decision-making and other dynamics within male-headed households affect continued SLM technology adoption. Understanding these dynamics is the first step towards designing policies and programmes that alleviate intra-household gender imbalances.

Women farmer groups offer effective platforms to facilitate women farmers' access to fundamental production factors such as seeds and equipment.

Women are not a homogenous group. Addressing widows (and female-headed households) and women living in maleheaded households with tailored activities is important in avoiding inflexible blanket solutions.

- Awareness-raising and integrating socia issues in project trainings can reduce socio-cultural hindrances to women's adoption of SLM technology. It is also important to recognise the impact women's contributions to the household can have if equal access to resources is given. Project implementers can steer joint reflections with farmers to dissolve these gender-specific barriers. 
Key Message \#5

Research is key for the design of gendersensitive approaches, and comprehensive data collection is indispensable to track progress on gender indicators. But monitoring activities need to go beyond female participation ratios and other numeric measures to track progress towards gender equality.

Gender analyses and Monitoring \& Evalvation (M\&E) is essential to track progress of gender-responsive approaches in programmes and projects. Yet, few resources (financial, time, and human) are invested in sex-disaggregated data collection and gender research, resulting in a lack of knowledge about long-term impacts on gender (Quisumbing \& Pandolfelli, 2010).

The big knowledge gap:

intra-household data

Studies documenting the gender gap in SLM have mostly been dedicated to comparing male to female-headed households (Theis et al., 2018). Yet, as discussed in the previous section, understanding intra-household dynamics is especially important to design tailored policies and important to design tailored policies and programmes for allwomen. Given that only $26.2 \%$ of total sub-Saharan households are female-headed (11.8\% in Burkina Faso in 2014 and $22.9 \%$ in Benin in 2012) (FAO, 2011; World Bank 2018), there is an urgent need to understand resource allocation and control within the household (Meinzen-Dick et al. 2017).
Current M\&E systems often lack qualitative data

In Benin and Burkina Faso, we found that where M\&E is conducted in SLM (related) projects, most reporting concentrates on quantitative indicators related to women's participation and SLM technology application rates (Assogba tech( 2017; Koudougou \& Stiem, 2017). Data on women's ratios, however, say little about the quality of participation. We found that women were reported as "reached through trainings on SLM technologies" but were actually not able to implement their acquired knowledge due to insecure tenure and limited access to labour and credit (Stiem-Bhatia et al., 2017).

Preliminary gender analyses to inform project design

Qualitative gender analyses, ideally during the project planning phase, can provide insights about intended, genderrelated changes, as well as M\&E methods to measure these. We further need to understand linkages between womn's adoption of SLM technologies and their bargaining power and control and decision-making within the household to effectively monitor progress of their empowerment (Theis et al., 2018)
Recommendations

Surveys with farmers do not inform sufficiently about women's need for support in SLM if male and female-headed households are only compared. Going the extra mile of collecting intra-household data is key to developing gender-sensitive approaches.

- Preliminary diagnostic gender studies can identify context-specific constraints to the adoption of SLM technologies by women and allow for better design and implementation of gender-sensitive approaches.

- Focusing purely on the participation of women in projects cannot adequately capture intrahousehold dynamics that can have important consequences on the distribution of a project's benefits. M\&E activities must therefore include qualitative assessments of how different qualitative assesments of how different approaches are ering women.
Gendered norms, attitudes and behaviours are shaped by the local context. The design of an M\&E systems that informs about progress towards gender equality and women's empowerment will therefore benefit from the inclusion of knowledge held by local stakeholders.

Composite measurement tools like the Women's Empowerment in Agriculture Index (WEAI) - which indicates women's control over critical parts of their lives in the household, community, and economy - can contribute to identify ways to overcome potential obstacles and constraints (Alkire et al., 2013).

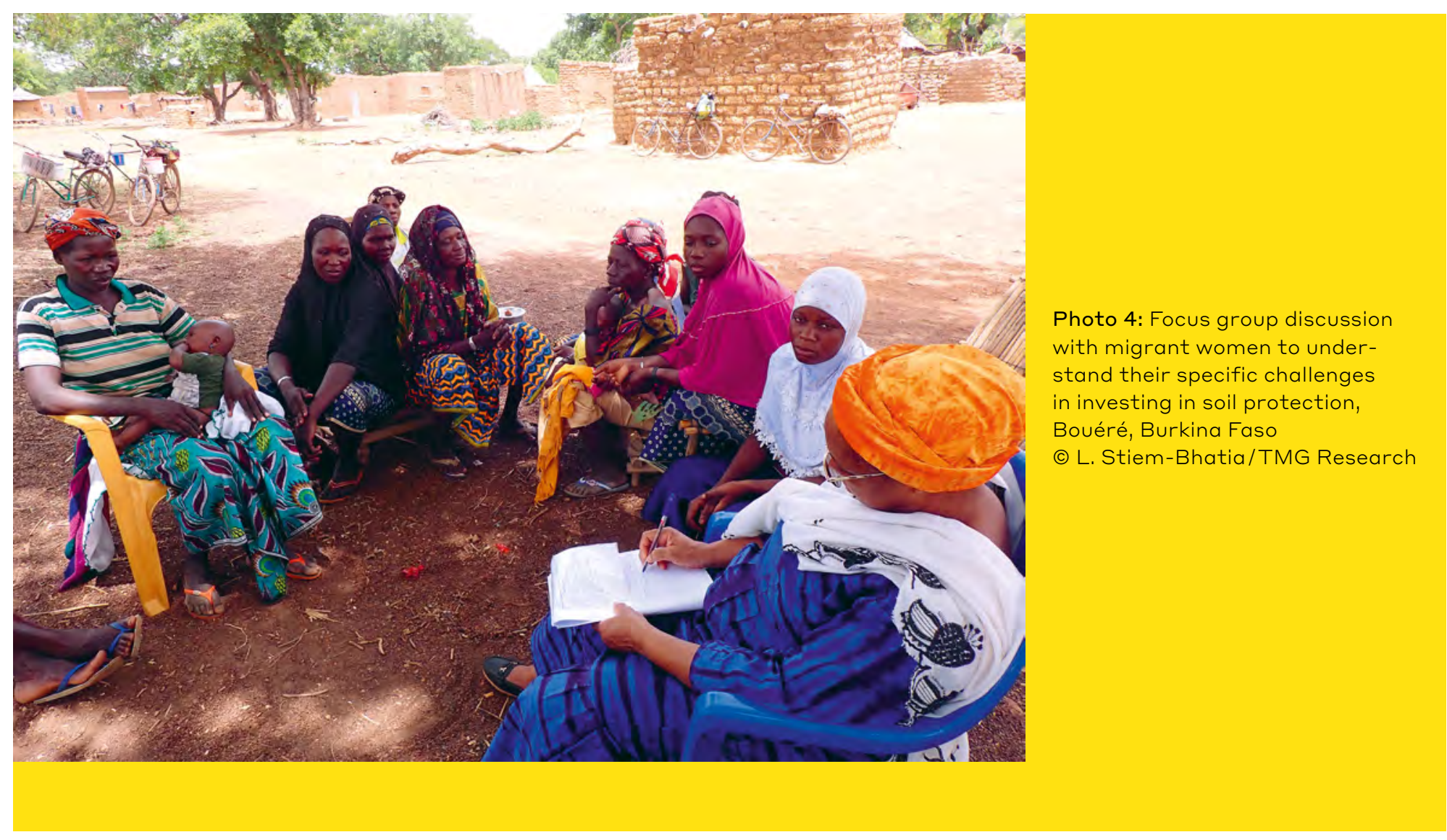




\section{Key Message \#6}

The persistent gender gap in agriculture can only be tackled through structural change by 2030 . Giving women smallholder farmers equal opportunities is fundamental to reaching gender equality in agriculture and requires everyone's involvement and commitment.

Reducing gendered barriers to SLM technology adoption is not sufficient; structural change is needed for the full and equal participation of women in sustainable land management. Women can only fully benefit from SLM interventions if they are truly empowered, i.e. if they have the agency to improve their social and economic situation considerably. Institutions that perpetuate gendered power imbalances must be transformed from within.

Gender equality is often equated with women alone despite being an issue of concern to both women and men (Mayoux, 2002). The involvement and commitment of men is crucial in promoting gender equality in SLM since men traditionally control land and other resources. Indeed, shifts and reconfigurations which strengthen women's interests and voice are unlikely to succeed unless men consider themselves partners and beneficiaries of this process (Farnworth et al, 2018). We observed that men were indeed key players in the process of securing land access for women in Burkina Faso (Stiem-Bhatia \& Koudougou, 2018).

\section{Recommendations}

Recognise and raise awareness about the importance of men's involvement and commitment in measures promoting gender equality.

Strengthen women's self-confidence and leadership to enable them to renegotiate power relations and decisions regarding access to and control of productive resources and their sustainable management.

Develop an approach to strengthen the awareness of women, men and community actors to overcome gender stereotypes and develop joint strategies to safeguard land in a sustainable way in order to deconstruct the social relations that hinder women's access to land and SLM technologies.

Project implementers and practitioners should challenge gender-discriminatory norms and practices and develop pathways together with the beneficiaries to promote gender equality. Improving the reach of women and other disadvantaged groups by agricultural extension workers could be an effective strategy.

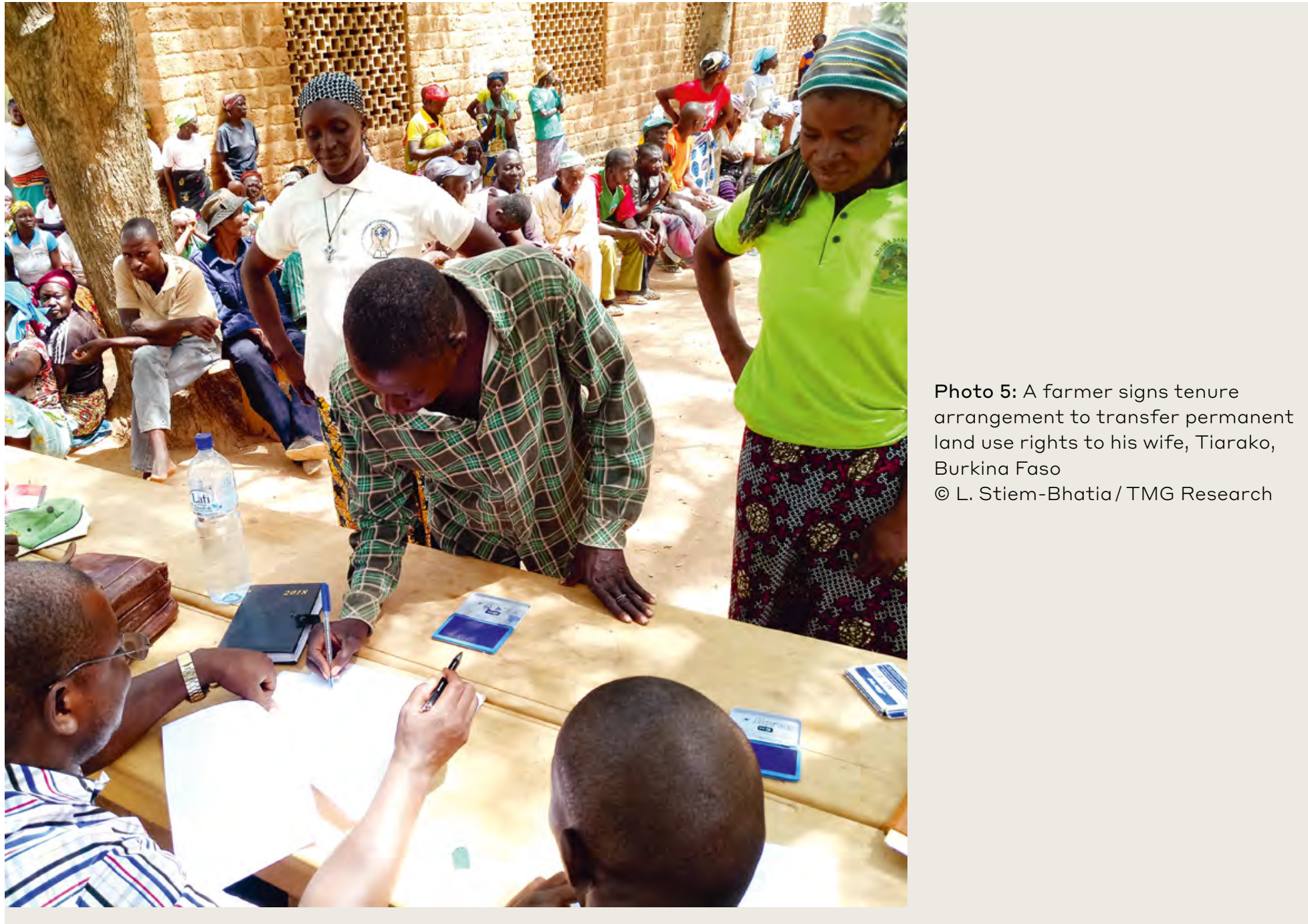

How men became (champions) in promoting land tenure security for women in Burkina Faso

Men played a crucial role in the land securing process in Burkina Faso, which was piloted by TMG Research with support from GRAF. Opinion and customary leaders were very supportive of permanent land use right transfer to women. Their endorsement of this process convinced reluctant land right holders to cede land use rights to women.

Raising awareness about the economic benefits of women's secure access to land made men open up to new ideas of managing and controlling land. Another important factor to win men over for this initiative was to involve them in decision-making. As heads of the family farms, men were first to suggest terms and conditions of the tenure agreements. Granting this first level of control to men and respecting traditional arrangements related to the bond of marriage was important to make men accept the idea of improving the tenure situation for women. On the contrary, many men accepted women's demands for increased surfaces of land, which would allow women to not only produce for subsistence use but also for the market. 


\section{References}

Alkire, S., Meinzen-Dick, R., Peterman, A., Quisumbing, A., Seymour, G., \& Vaz, A. (2013). The Women's Empowerment in Agriculture Index. World Development. https://doi.org/10.1016/j.worlddev.2013.06.007

Assogba, S. C.-G., Akpinfa, É., Gouwakinnou, G., \& Stiem, L. (2017). La Gestion Durable des Potsdam, Germany.

Doss, C., Meinzen-Dick, R., Quisumbing, A., \& Theis, S. (2018). Women in agriculture: Four myths. Global Food Security, 16 (October 2017), 69-74. https://doi.org/10.1016/j.gfs.2017.10.001

ELD Initiative \& UNEP (2015). The Economics of Land Degradation in Africa: Benefits of Action Outweigh the Costs. Retrieved fom https://bit.ly/2h0SKCK

FAO. (2011). The state of food and agriculture. Women in agriculture. Closing the gender gap for development. Lancet (Vol. 2). Rome. Retrieved from http://www.pubmedcentral. nih.gov/articlerender.fcgi?artid=3291936\&tool=pmcentrez\&rendertype=abstract

FAO \& ITPS. (2015). Status of the world's soil resources (SWSR)-main report. Food and Agriculture Organization of the United Nations and Intergovernmental Technical Panel on Soils, Rome, Italy, 650

Farnworth, C. R., López, D. E., Badstue, L., Hailemariam, M., \& Abeyo, B. G. (2018). Gender and agricultural innovation in Oromia region, Ethiopia: from innovator to tempered radical. Gender, Technology and Development, 22(3), 222-245.

IPBES (2018): Summary for policymakers of the assessment report on land degradation and restoration of the Intergovernmental Science-Policy Platform on Biodiversity Brink, M. Cantele, B. Erasmus, U. Fisher, T. Gardner, T. G. Holland, F. Kohler, U. S. Kotiaho, G. Von Maltitz, G. Nangendo, R. Pandit, U. Parrotta, M. D. Potts, S. Prince, M. Sankaran and L. Willemen (eds.). IPBES secretariat, Bonn, Germany. 44 pages

Koudougou, S., Stiem-Bhatia, L., Bary, H., \& Tall, F. (2017). Genre, foncier et gestion durable des terres au Burkina Faso. Potsdam, Germany.

Koudougou, S., \& Stiem, L. (2017). La Gestion Durable des Terres au Burkina Faso: une analyse d'expériences de projets dans le Houet, le Tuy et le loba. Institute for

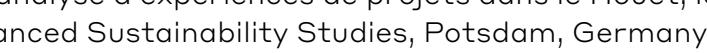
https://doi.org/10.2312/iass.2017.006

Lavison, R. K. (2013). Factors influencing the adoption of organic fertilizers in vegetable production in Accra (Doctoral dissertation, University of Ghana).

Mayoux, L. (2002). Microfinance and women's empowerment: Rethinking 'best practice'. Development Bulletin, 57(76-80).

Mburu, J., \& Kiragu-Wissler, S. (2018). Sustainable Land Management in Western Kenya: An Analysis of Project-Basd Interventions. Berlin, Germany.

Meinzen-Dick, R., Quisumbing, A., Doss, C., \& Theis, S. (2017). Women's land rights as a pathway to poverty reduction: Framework and review of available evidence (IFPRI pathway to poverty reduction: Framework and
Discussion Paper No. 01663). Washington, DC.

Mignouna, D. B., Manyong, V. M., Rusike, U., Mutabazi, K. D. S., \& Senkondo, E. M. (2011). Determinants of adopting imazapyr-resis

Mishra, K., Abdoul, S. G., Miranda, M. U., \& Diiro, G. M. (2015). Gender and Dynamics of Technology Adoption: Evidence from Uganda (No. 330-2016-13685)

Muriithi, B., Diiro, G., Berresaw, M. K., \& Muricho, G. (2018). Does gender matter in the adoption of sustainable agricultural technologies? A case of push-pull technology in Kenya. A Case of Push-Pull Technology in
Economic Policy Working Paper, (2018-05).
Ndiritu, S. W., Kassie, M., \& Shiferaw, B. (2014). Are there systematic gender differences in the adoption of sustainable agricultural intensification practices? Evidence from Kenya. Food Policy, 49(P1), 117-127.

https://doi.org/10.1016/j.foodpol.2014.06.010

Nkonya, E., Mirzabaev, A., \& Von Braun, J. (Eds.). (2016). Economics of land degradation and improvement: a global assessment for sustainable development. Cham, Germany: Springer Open.

Obisesan, A. (2014). Gender differences in technology adoption and welfare impact among Nigerian farming households.

Omonona, B. T., Oni, O. A., \& Uwagboe, A. O. (2006). Adoption of improved cassava varieties and its welfare impact on rural farming households in Edo State, Nigeria. Journa of agricultural \& food information, $7(1), 39-55$.

Palacios-Lopez, A., Christiaensen, L., \& Kilic, T. (2015). How much of the labor in African agriculture is provided by women? The World Bank.

Quisumbing, A. R. \& Pandolfelli, L. (2010). Promising Approaches to Address the Needs of Poor Female Formers: Resources, Constraints, and Interventions. World Development, 38(4), 581-592. https://doi.org/10.1016/j.worlddev.2009.10.006

Smith, L. C., \& Haddad, L. U. (2000). Explaining child malnutrition in developing countries: A cross-country analysis (Vol. 111). Intl Food Policy Res Inst.

Stiem-Bhatia, L., \& Koudougou, S. (2018). Innovations for women's land access. Rural 21 (03).

Stiem-Bhatia, L., Onibon Doubogan, Y., \& Badou Savi, A. (2017). Les pratiques de la gestion durable des terres au Bénin : une analyse sous l'angle du genre. Po. https://doi.org/10.13140/RG.2.2.30897.48485

Theis, S., Lefore, N., Meinzen-Dick, R., \& Bryan, E. (2018). What happens after technology adoption? Gendered aspects of small-scale irrigation technologies in Ethiopia, Ghana, and Tanzania. Agriculture and Human Values, 35(3), 671-684. https://doi.org/10.1007/s10460-018-9862-8

Theriault, V., Smale, M., \& Haider, H. (2017). How does gender affect sustainable intensification of cereal production in the West African Sahel? Evidence from Burkina Faso. World Development, 92, 177-191.

United Nations Convention to Combat Desertification (UNCCD). (2017). The Global Land Outlook, first edition. Bonn, Germany

reat to food security: a global assessment. $J$ Environ Earth Sci, 5, 13-21.

World Bank, World Bank Open Data. (2018). Female headed households (\% of households with a female head) [Data file]. Retrieved from https://data.worlabank.org/indicator/SP.HOU.FEMA.ZS?locations=BF-BU 
TMG Working Paper May 2019

TMG - Think Tank for Sustainability TMG Research gGmbH

EUREF-Campus 6-9

10829 Berlin, GERMANY

Telephone: (+49) 3092107407 00

Email: info@tmg-thinktank.com

Website: www.tmg-thinktank.com

This publication is made possible with the financial support by the German Federal Ministry of Economic Cooperation and Development (BMZ).

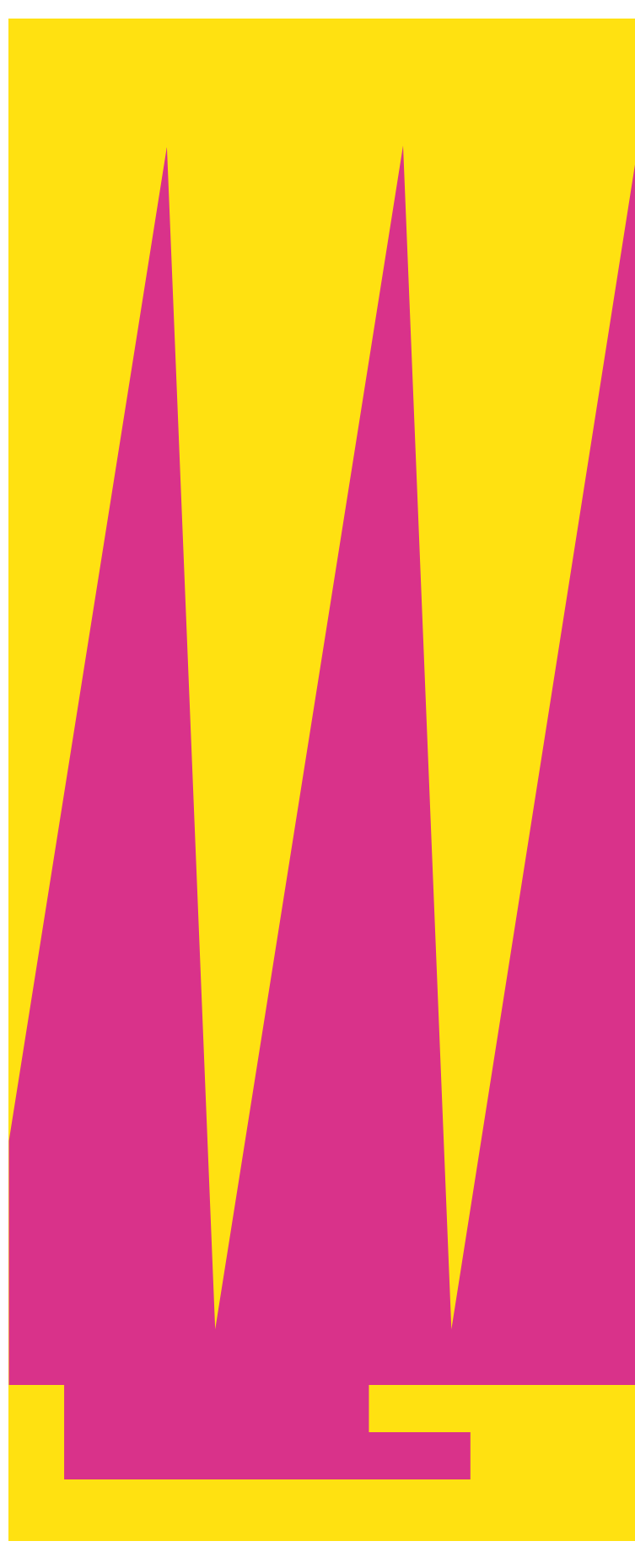

